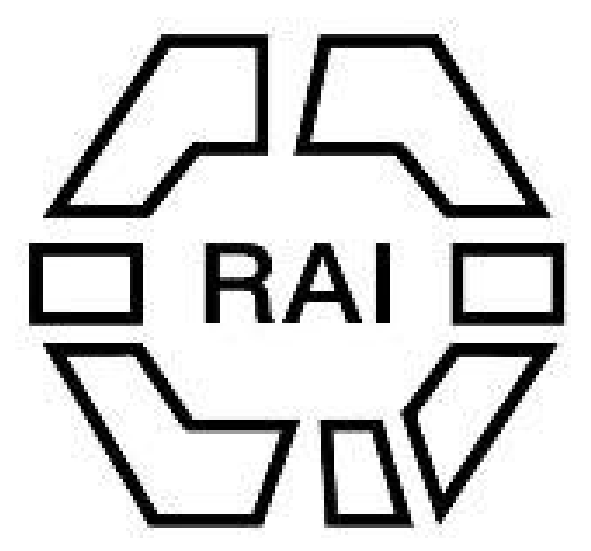

\title{
WILEY
}

\section{Maori Beliefs Concerning the Human Organs of Generation}

\section{Author(s): Elsdon Best}

Source: Man, Vol. 14 (1914), pp. 132-134

Published by: Royal Anthropological Institute of Great Britain and Ireland

Stable URL: http://www.jstor.org/stable/2787890

Accessed: 27-06-2016 09:47 UTC

Your use of the JSTOR archive indicates your acceptance of the Terms \& Conditions of Use, available at

http://about.jstor.org/terms

JSTOR is a not-for-profit service that helps scholars, researchers, and students discover, use, and build upon a wide range of content in a trusted digital archive. We use information technology and tools to increase productivity and facilitate new forms of scholarship. For more information about JSTOR, please contact support@jstor.org.

Royal Anthropological Institute of Great Britain and Ireland, Wiley are collaborating with JSTOR to digitize, preserve and extend access to Man 
The type of furnace differs essentially from that which was used by the Anyanja and $Y a o$, but $I$ am unable under my present circumstances to state whether it should be associated with the Angoni of Zulu origin or with the Atumbuka, a division of the Batumbuka from further west, among whom they came

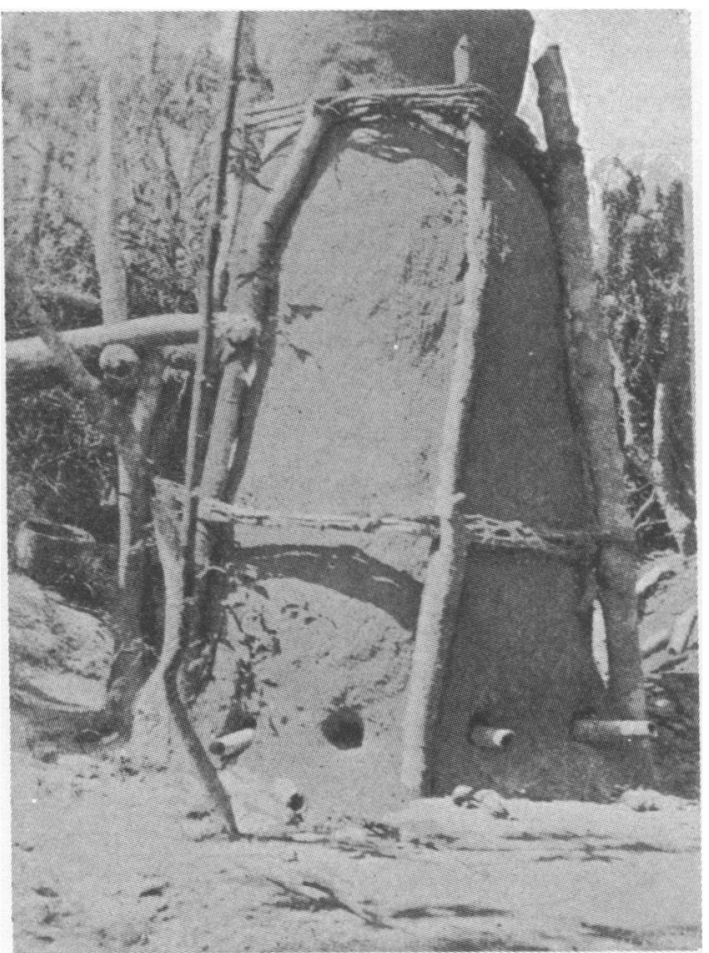

ANGONI SMELTiNg FURNACE. as a conquering race and among whom they settled and intermarried.

The furnace, ngango, is an upright one, about 10 feet in height, somewhat bottle-shaped and made of clay, supported by wooden poles let into the ground bound round the outside. At the base there are eight holes through which earthenware pipes having an internal diameter of 3 inches are inserted to create the draught (nchelwa). The furnace is built on a slight slope, which allows of a hole being made at the lower side from which the slag escapes; slag is called by the word used for fæces. A rough platform of logs is made up against the upper side for convenience of those filling the furnace. It is filled almost to the neck with charcoal (makala) made from the "Kamponi" tree; this is then ignited from the top and a mixture of charcoal and iron stone (tari) in equal proportions is added at intervals. The operation lasts for two days; an opening is then made at the base of the furnace and the iron, which has collected in a circular trough at the bottom, is extracted.

H. S. STANNUS.

New Zealand.

Best. Maori Beliefs concerning the Human Organs of Ceneration. 6$\}$
By Elsdon Best.

One of the most singular beliefs of the Maori of New Zealand is that concerning the inherent power of the organs of generation in the genus homo. This belief is by no means clear to us, hence we can but give the few notes we have collected on the subject. So far as we can see into this curious belief, the general idea seems to be that the power of the female organ is destructive, and that of the male organ is preservative and protective in its nature. In perusing a collection of old time myths and beliefs obtained from the Awa folk of the Bay of Plenty district, we of ten encounter a singular expression applied to the female organ; it is termed the whare o aitua, which we can ouly render as "the abode of misfortune"; it is the emblem of trouble, if not of death itself. The following sentence occurs in an old cosmogonic myth: "The aperture of misfortune is below, with Papa (the "Earth Mother" "); the realm (or origin) of life is above." Also, when 'Tate was seeking the female element, the Sky Parent said to him, "The female element is below."

An old man of many summers once said to the writer, "It was the tawhito " of Hine-nui-te-po that destroyed Maui." Now this word tawhito, in the 
vernacular, means "old," but is applied in myths, \&c., to the generative organs. Hine-nui-te-po is a queen of the underworld, whose care is the spirits of the dead, and destroyed Maui, the hero, as he was entering her body by way of the tawhito in order to gain eternal life for man.

Tane, who represents the male element, Tane the fertiliser, is sometimes said to have been the cause of the introduction of death into the world, apparently because of his incestuous act towards his daughter, who thereupon descended to the underworld, where she is known as Hine-nui-te-po.

The Maori ever recognised sex in nature, and his views concerning the male and female elements are highly interesting. The Tama-Tane, or male element, and Tama-Wahine, or female element, enter into all nature, apparently. 'Thus, the right hand is the male hand and the left the female. The ocean to the east of these islands is the female sea, that of the west the male sea. Both elements also enter into religious rites, hence the introduction of women into many ceremonies, the singular acts of the ruahine, who first crosses the threshold of a new house, and also lifts the tapu from a newly erected fortified place. The power of sex is also recognised when the services of the first-born female of a family of rank is employed to step over the body of a man who has lost his spiritual health and intellectual vigour by transgressing some law of tapu, which act will restore him and bring him back to normal conditions.

The way by which man is born into the world is termed the house of death, because, so soon as he enters the world from that organ, he is subject to trouble, misfortune, disease, and death. He resembles not the primal beings, the offspring of the Sky Parent and Earth Mother. Observe the Children of Light (the heavenly bodies) on the breast of Rangi (sky), who live for ever, and know not death-such was a remark made to us by a native. Another remarked, "The female organ is " the destroyer of mankind." Now, compare the following given by a native of India, "The goddess Kali is the emblem of sakti (i.e., of the feminine principle, " symbolising in this case destructive energy) and the image gives a vivid idea of " the destruction and havoc inevitably to follow on the exercise of sakti. The "sakti is inherent in all, but in a sleeping state while not in action, and the " moment it is stirred up, it manifests itself in overwhelming force."

Tutaka, an old man of the Tuhoe tribe, once said to the writer, in response to certain queries: "The male organ is a destroyer of man in one sense, for, by its " powers, the workers of magic are confounded. But it is really the saviour of " man. The male organ is the tangata matua (? parent person). If two persons " are engaged in a contention, and one thinks that the other has an intention of " bewitching him, he at once withdraws to a secluded spot, takes hold of his penis, " and draws back the foreskin. He then returus, holding his hand half closed as " though still grasping his penis, expectorates into that hand, and makes a motion " with it towards his adversary as though throwing something at him. 'That act " will save him, and will destroy his opponent (or render his magic futile)."

In this account no mention is made of any charm uttered by the operator, such as are given by other informants. Tikitu, of the Bay of Plenty, said: "The per" formance termed kai ure is to avert magic. If you are endeavouring to bewitch " me, I grasp my ure, draw the foreskin back, and repeat these words :-

"Kai ure nga atua, Kai ure nga tapu, Kai ure ou makutu.

"This act will deprive your magic of all power; if correctly performed, that magic " has no effect, it becomes powerless before the powers of the ure." 
A very old man of the Awa tribe, with whom the writer was on most intimate lerms, sent the following message:- "Friend; I am sending you the means by " which you may ward off the magic arts of your enemies. This charm that I send " you is the kai ure; it is the salvation of man. Now, when you are aware that " a person is trying to bewitch you, though he be before you, or at your very side, " yet will this destroy his magic powers, and turn them against himself. Slip your " hand down inside your clothing and grasp your penis, and repeat the charm quietly, "so that none may hear it. Thus shall you retain life."

The same old fellow, when discoursing on the subject of the vitality and fertility of the white people, as opposed to the decadent Maori, remarked: "To " my mind, the cause of the health and universal welfare of the white folks is " found in the fact that, ever as they sleep, they keep within their rooms the koutu " mimi (chamber), it is never absent; and assuredly that vessel (i.e., the contents " thereof) represents the tawhito (penis) that is the saviour of man, preserving his " welfare."

These are samples of the mentality of the Maori, and the extraordinary channels of thought in which his mind has run for many centuries. Nor is it any light task to get at the meaning of these amazing beliefs, so different are our modes of thought.

It is of interest to note that, in Southern Asia, the urine of cows is, or was, used in purification rites, and that the holding of the penis, when wishing to impart power or solemnity to a verbal compact, as a promise or vow, is alluded to in the Bible.

In former times, when a native wished to dispel a frost that might injure his crops, he took a firebrand to the mianga, or urinal, and there waved it to and fro.

More might be written on the subject of the native view of the generative principle in nature, and more information might be collected on such topics. The origin of such customs as ceremonial copulation, and the extraordinary ngau pagpae (biting the beam of a latrine) ceremony, seem to be lost, but such items are worth recording for purposes of comparison.

ELSDON BEST.

Archæology.

Passmore.

Rarity of Large Flint Implements in Gloucestershire. $B y A . D$. Passmore.

Canon Greenwall in his preliminary remarks on the district and tumuli of Nether Swell, in N. Gloucestershire,* discusses the remarkable absence of large flint implements, such as axes or adzes.

Thousands of arrowheads, flakes, and scrapers have been found, but only two halves of axes were to be seen amongst an enormous collection.

During a recent sojourn in that region of Gloucestershire, the writer, while finding flints, came to the following conclusions, which seem to explain the absence of the larger implements.

In the horizon under discussion there is no indigenous flint, and therefore the raw material for working into implements, or the finished implements themselves, would be imported, probably from Wiltshire. This means that flint at Nether Swell would be rare, and in troublous times, when commerce was temporarily interrupted, would become scarce and valuable. In Wiltshire, where flints are common, a man who broke a large axe could afford to throw away the pieces and pick up a

* British Barrows, p. 443. 